\title{
Introduction
}

\section{Dear Graeme}

I have read your manuscript with the greatest of interest. You have recorded your experiences in a way that is perhaps not possible in more formal histories, and, while not departing from the authenticity of events, by your personal reactions you have added an outstanding account of the human factors which are ultimately so important. ${ }^{1}$

In 1963, Second World War veteran Graeme Ogden's memoir of wartime naval service entered a fast-flowing tide of personal narratives published by British military personnel who had fought in that conflict. Throughout the seven decades since the end of the Second World War, increasing numbers of these books appeared in print and became cemented into what Graham Dawson identifies as an enduring popular 'pleasure-culture of war' in Britain. ${ }^{2}$ Yet as Rear-Admiral Rupert Sherbrooke's foreword to Ogden's My Sea Lady articulates, they also proffer an immense value to the social and cultural historian of warfare. Positioning published veteran memoirs as repositories of vital information about the ways in which former servicemen remembered, understood, and mediated their war, The Veterans'Tale establishes the unique contribution of post-war published military memoirs to the aggregate of scholarship of modern war and memory. The veterans' memoirs of the Second World War belong to a lengthy cultural tradition of telling and receiving old soldiers' stories in Britain. Indeed, when prophesying his soldiers' creation of memories of Agincourt, William Shakespeare's 'Henry V' sagely observes, 'Old men forget: yet all shall be forgot,/ But

${ }^{1}$ Rear-Admiral Rupert Sherbrooke, foreword to Graeme Ogden, My Sea Lady: The Story of H. M. S. Lady Madeleine From February 1941 to February 1943 (London: Hutchinson, 1963), p. 9.

${ }^{2}$ Graham Dawson, Soldier Heroes: British Adventure, Empire and the Imagining of Masculinities (London: Routledge, 1994), p. 4. 
he'll remember with advantages/ What feats he did that day.' ${ }^{3}$ The playwright alluded here to the veterans' recollections of fighting, and the emotional meanings that they later came to ascribe to battle. The same process of remembering with 'advantages', of finding order and significance in combat during the reflective leisure of peacetime, also drove the creation of the Second World War veterans' stories.

That wily bird, Shakespeare, was well aware of the fighting man's love of telling a good story. The embellishments, the factual discrepancies, the shifting and conflicting memories which naturally occur within the narratives of the soldier-raconteur and are wryly identified by the playwright as 'advantages' of the veteran's memory, might easily be regarded as maddening disadvantages to the historical researcher. The Veterans' Tale, however, suggests that these inconsistencies of recall and evident subjectivities of veteran war stories are precisely what make them a fascinating and rich source of evidence about the experience of war as it is lived and remembered throughout a former soldier's lifetime. Old soldiers may forget much about their lives, but as Shakespeare remarks, they also often remember and retell their participation in the great events of war for a long time after that war has ended. Rather like the Battle of Agincourt in Henry $V$, a distinctive and spellbinding national mythology was tightly woven around the Second World War in Britain. Swathed in popular images and discourses of the nation's intense pride in attaining victory over the evils of Nazi fascism, the Second World War represented a conflict in which the British ex-serviceman could legitimately exhibit personal pride in his own participation. Unravelling the individual and collective tales of battle that British veterans narrated and published between 1950 and 2010, this book trains fresh sights upon the experience and meaning of the Second World War to those who won it.

As the Second World War slides out of living memory in Britain, The Veterans'Tale examines the lived, remembered, and recorded experience of battle within veteran memoir. Traditionally, scholarly investigation of military memoirs has been enacted within the discipline of literary criticism, a field which includes such notable works as Paul Fussell's The Great War and Modern Memory (1975) and Samuel Hynes' The Soldiers' Tale (1998). ${ }^{4}$ Fussell's research marked the beginning of new scholarly attitudes towards war literature, playing a pivotal role in shaping understandings of the canon of First World War texts as part of a broader

${ }^{3}$ William Shakespeare, HenryV, in William Shakespeare:The CompleteWorks, (ed.) W. J. Craig (London: Magpie Books, 1993), p. 491.

${ }^{4}$ Paul Fussell, The Great War and Modern Memory (London: Oxford University Press, 1975); Samuel Hynes, The Soldiers' Tale: Bearing Witness to Modern War (London: Pimlico, 1998). A more recent addition to this list is Alex Vernon (ed.), Arms and the Self:War, the Military and Autobiographical Writing (Kent (Ohio): Kent State University Press, 2005). 
myth-making process within twentieth-century British society. His analysis of the interplay between war, personal narrative, and memory uncovered the ways in which British experience on the Western Front between 1914 and 1918 was 'remembered, conventionalized and mythologized' in literary form. ${ }^{5}$ This approach proved 'revolutionary' to furthering scholarly understandings of war, since it demonstrated that battlefield literature offered a vehicle for the expression of collective experience. ${ }^{6}$ The Veterans' Tale absorbs these ideas to examine how the veteran-memoirists of the Second World War also engaged in a proprietorial form of myth-making in order to shape scholarly, cultural, and official remembrance of 'their' war. In mapping the literary scholarship of military memoirs, Hynes' work provided a subsequent landmark text within the field, making a staunch effort to survey British and American servicemen's memoirs from the First and Second World Wars, and the Vietnam conflict of the 1960s and 1970s. Expanding upon the limited number of sources interrogated by Fussell, Hynes insisted upon the importance of privileging the narratives of the 'one-book men', authors who told their story and then dropped quietly back into anonymity again. ${ }^{7}$ Despite this laudable objective, a serious drawback of Hynes' study is its over-reliance upon the more 'literary' and self-conscious popular texts from the Second World War, which does little to rescue the critical mass of military memoirs still consigned to relative oblivion. Building on Hynes' foundations, The Veterans' Tale thus extends its scope of enquiry to include a much wider range of these books. Nevertheless, Hynes' consideration of some of the formal qualities of military memoir underpins the identification of narratives examined in this book, which also acknowledges Hynes' salutary reminder that war memoirists are invariably a self-selecting group. Correspondingly, it is contended here that attention must be paid to the reasons why these authors, whether they were prolific writers or 'one-book men', made a decision to pen and make public a narrative of their combat experiences.

To these path-finding literary scholars, especially Hynes, a considerable debt is acknowledged in my own study. However, whilst some of their techniques of literary criticism structurally underpin my own analysis of war memoirs, The Veterans' Tale situates itself firmly in the culturalmilitary history camp. Addressing themes of war, memory, and emotions in relation to veteran-memoirists, this study is intended to fill a critical and inexplicable gap in the rapidly expanding field of historical enquiry into military life-writing. In recent years, military memoirs have come to exert an evident appeal for a growing number of researchers across

\footnotetext{
${ }^{5}$ Paul Fussell, The Great War and Modern Memory, rev. ed. (Oxford: Oxford University Press, 2000), p. ix.

${ }^{6}$ Susanna Rustin, 'Hello to all that', The Guardian, 31 July 2004.

${ }^{7}$ Hynes, The Soldiers'Tale, p. xv.
} 
the fields of history and social geography. Under the 'war and society' umbrella, military memoirs have become increasingly promoted as an essential means of recovering the experience of battle and understanding the complex relationship between war, the soldier, and society. In 2008, Brian Bond's Survivors of a Kind combined the perspectives of cultural and military historians in his approach to British First World War memoirs spawned by the Western Front. ${ }^{8}$ Crucially, Bond established that the long-term effects of the conflict upon combatants could be assessed through their personal narratives. This view exerts a formative influence over The Veterans'Tale, which examines the ways in which post1950 military memoirs of the Second World War recorded the enduring impact of battle upon veterans. As a result of a recent cultural turn towards military life-writing, the chronological margins of studying war memoirs have been considerably expanded outwards. Neil Ramsey and Catriona Kennedy have traced soldiers' narratives of the Revolutionary and Napoleonic Wars, whilst Yuval Noah Harari proffers a comprehensive examination of Renaissance military memoirs. Directing scholarly attention towards the more recent twentieth century, the works of K. Neil Jenkings, and Rachel Woodward address contemporary soldiers' life-writing from wars in the Falklands, the Gulf, Northern Ireland, Afghanistan, and Iraq. ${ }^{9}$ In this book, a slightly different emphasis is placed on the identity of the military memoirist as an ex-serviceman, or an old soldier, whose authorship is reflective and constructive rather than one of straightforward reportage. This allows for the long-term physical, psychological, and emotional impact of war upon an ex-combatant to be significantly opened up. The central pillar of this book is a scrutiny of the unique identity of the post-war military memoir which 'records the remembered war that persists in the mind through a lifetime. ${ }^{10}$ This

${ }^{8}$ Brian Bond, Survivors of a Kind: Memoirs of the Western Front (London: Continuum, 2008).

${ }^{9}$ Neil Ramsey, The Military Memoir and Romantic Literary Culture, 1780-1835 (Farnham: Ashgate, 2011); Catriona Kennedy, Narratives of the Revolutionary and Napoleonic Wars: Military and Civilian Experience in Britain and Ireland (Basingstoke: Palgrave Macmillan, 2013); Yuval Noah Harari, Renaissance Military Memoirs:War, History, and Identity, 14501600 (Woodbridge: Boydell Press, 2004); Harari, 'Armchairs, Coffee, and Authority: Eye-Witnesses and Flesh-Witnesses Speak about War, 1100-2000', fournal of Military History, 74:1 (January 2010), 53-78; Vernon, Arms and the Self; Rachel Woodward and K. Neil Jenkings, 'Soldiers' bodies and the contemporary British military memoir', in War and the Body: Militarisation, Practice and Experience (ed.) Kevin McSorley (London: Routledge, 2013), 152-64; K. Neil Jenkings and Rachel Woodward, 'Communicating War through the Contemporary British Military Memoir: The Censorships of Genre, State, and Self', fournal of War E Culture Studies 7:1 (2014), 5-17.

10 Samuel Hynes, 'Personal Narratives and Commemoration', in War and Remembrance in the Twentieth Century, (eds.) Jay Winter and Emmanuel Sivan (Cambridge: Cambridge University Press, 1999), p. 211. 
book thus represents the first extended scholarly treatment of veteran memoirs, situating these texts as particularly valuable to historians of warfare because of their capacity to shed light upon the ex-combatant's retrospective remembrance and understanding of battle.

Surprisingly, the voices of British Second World War veteran-memoirists have yet to be heard on a collective scale within the field of scholarship of war, memory, and personal narratives. Towards the end of the market that caters for more popular histories of wartime martial experience, historians have relied heavily on mining these accounts of soldiers, sailors, and aircrew for the vivid details and human emotions that lend colour to battle for wider reading audiences. ${ }^{11}$ Among the extensive terrain of Second World War historiography, the post-war memoirs of former servicemen have been dotted here and there, but their use has been mostly restricted to the provision of salient anecdotes or fleeting descriptions of battle conditions. Given both the fruitful and expanding nature of scholarly enquiry into military life-writing and the Second World War's continued resonance within British national culture, the gaping hole in academic scholarship of the myriad war memoirs generated by the 1939-45 conflict is remarkable. To date, despite a burgeoning literature examining the memoirs of British military captivity in the Far East during the war, no single purpose-built work exclusively addresses British military memoirs of the Second World War. ${ }^{12}$ Where they have been cursorily utilised, these books are often somewhat crudely sandwiched into wider discussions that focus upon the narratives of First World War and Vietnam soldiers as a twentieth century literature of disillusionment. Within recent years, Yuval Noah Harari has deservedly become an authority on the genre of Renaissance military memoirs, but the clarity and insight that he brings to his approach to these documents is not entirely matched by his use of twentieth century military life-writing in order to exhibit the distinctive design in structure

${ }^{11}$ See, for example, Patrick Bishop, Fighter Boys: Saving Britain 1940 (London: HarperCollins, 2003); Brian Lavery, In Which They Served: The Royal Navy Officer Experience in the Second World War (London: Conway, 2008); Glyn Prysor, Citizen Sailors: The Royal Navy in the Second World War (London: Viking, 2011); Michael G. Walling, Forgotten Sacrifice: The Arctic Convoys of World War II (Oxford: Osprey Publishing, 2016); Kevin Wilson, Men of Air: The Doomed Youth of Bomber Command, 1944 (London: Weidenfeld \& Nicolson, 2007).

12 See, for example, Frances Houghton, “To the Kwai and Back": Myth, Memory and Memoirs of the "Death Railway" 1942-1943', Fournal of War and Culture Studies, 7:3 (2014), 223-35; Lizzie Oliver, Prisoners of the Sumatra Railway: Narratives of History and Memory (New York: Bloomsbury, 2018); Sibylla Jane Flower, 'Captors and Captives on the Burma-Thailand Railway', in Bob Moore and Kent Fedorowich (eds.), Prisoners of War and their Captors in World War II (Oxford: Berg, 1996), pp. 227-52; Roger Bourke, Prisoners of the Fapanese: Literary Imagination and the Prisoner-of-War Experience (Queensland: University of Queensland Press, 2006). 
and content of the earlier accounts. Although this method allows a number of valuable conclusions about Renaissance testimonies to be drawn, it also results in a collection of rather frustrating generalisations about the later personal narratives of combat. Harari's broad claim that scholars studying twentieth-century war memoirs 'have reached the almost unanimous conclusion that ... soldiers have become disillusioned with war, and their own image has partly changed from that of heroes to that of victims' is not particularly helpful to any investigation of Second World War memoirs. ${ }^{13}$ The veterans' tale of frontline service between 1939 and 1945 shows no sign at all of the disenchantment or betrayal of ideals which may be typically read into the canon of First World War and Vietnam soldiers' testimonies. In fact, the Second World War veteran-memoirists were inordinately proud of their wartime service and clearly subscribed to a concept of the 1939-45 conflict as a 'Good War'. ${ }^{14}$ Any public or private suggestion that these men ought to feel guilty or victimised by their wartime experiences typically received extremely short shrift from them.

The theoretical orientation of this book is rooted in a number of fields, weaving together key tenets from memory studies, auto/biographical studies, and the emergent field of history of the emotions to suggest an innovative approach to discussing military memoirs. Within the extant scholarship, valuable new ways of understanding the wider relationship between war and society were offered by a 'boom' in studies of memory which occurred during the 1980s. ${ }^{15}$ Academics from multi-disciplines shifted interpretations of private and 'collective' memory from passive to active, relocating the changeability, flexibility, and permeability of memory as a source of interest and advantage to the scholar. Fundamentally, war memoirists came to be viewed within this context as 'makers' who create narratives of remembrance in which meaning is emergent rather than fixed, and Jay Winter and Samuel Hynes have emphasised a need to open up investigation of the place of soldiers' tales in relation to broader historical remembrance. ${ }^{16}$ The Veterans' Tale responds to this need by enquiring more deeply into the relationship between military memoirs and wider official, scholarly, and cultural remembrance of the Second World War. To a great extent, this study of veteran memoirs is thus informed by the ideas of leading scholars within the field of memory

${ }^{13}$ Yuval Noah Harari, 'Martial Illusions: War and Disillusionment in Twentieth-Century and Renaissance Military Memoirs', fournal of Military History, 69:1 (2005), 43.

${ }^{14}$ Studs Terkel, 'The Good War': An Oral History of World War Two (New York: Pantheon, 1984).

15 Jay Winter, Remembering War: The Great War Between Memory and History in the Twentieth Century (New Haven:Yale University Press, 2006), p. 1.

${ }^{16}$ Ibid., p. 9; Hynes, 'Personal Narratives and Commemoration', pp. 205-6. 
studies. In particular, it draws upon the theories of Maurice Halbwachs, who demonstrates that memories do not simply exist within a vacuum, but are instead composed within 'social frameworks' that exert an influence upon the recall, recognition, and localization of memory. ${ }^{17}$ Standing at the intersection of private and public memory, the published veteran memoir is thus ideally placed to illumine the shifting and often conflicting affinity between individual and 'collective' remembrance of the Second World War in Britain. In analysing the production and reproduction of veteran memory in published literary form, this study also relies heavily upon the work of Henri Rousso, who identifies any source that proposes a deliberate reconstruction of an event for a social purpose as 'carriers' or 'vectors' of memory. ${ }^{18}$ Weaving these ideas into its approach towards published veteran memoirs, TheVeterans'Tale locates these narratives as precious sites from which the veterans could dictate and contest representations of the Second World War.

Oral histories have also come to occupy an important place in examining narratives of war and memory during the twentieth century. In many ways, an oral history bears a marked similarity to a written memoir in that both reconstruct experience from memory and attempt to access an often long-past voice from the situation of the present. Consequently, The Veterans' Tale engages with key ideas produced from within the domain of oral histories of war. Alistair Thomson's ground-breaking Anzac Memories (1994) explores the processes through which Australian veterans of the First World War composed their memories of war across a lifetime, and how their own later-life experiences and understandings influenced their recollections. ${ }^{19}$ Thomson's examination of the ways in which meanings about the past evolved for the old soldiers whom he interviewed thus highlights the necessity to bear in mind that lived and remembered experiences of battle are shared points on the continuum of a lifetime. TheVeterans'Tale also considers the work of Penny Summerfield in terms of the composure and articulation of wartime self and experience. Summerfield's study of women's oral histories of the Second World War reminds that personal testimony is always inter-subjective, drawing from generalised discourse to construct the particular personal subject. ${ }^{20}$

${ }^{17}$ Maurice Halbwachs, On Collective Memory, trans. Lewis Coser (Chicago: University of Chicago Press, 1992), p. 38.

18 Henri Rousso, The Vichy Syndrome: History and Memory in France since 1944, trans. Arthur Goldhammer (Cambridge (MA): Harvard University Press, 1991), p. 219.

19 Alistair Thomson, Anzac Memories: Living With the Legend (Oxford: Oxford University Press, 1994)

${ }^{20}$ Penny Summerfield, Reconstructing Women's Wartime Lives: Discourse and Subjectivity in Oral Histories of the Second World War (Manchester: Manchester University Press, 1998), p. 15. 
Bearing this in mind, The Veterans'Tale maintains a particular focus upon the wider discourse, language, and imagery that was available to the veteran-memoirist to reconstruct both his experiences of battle and his sense of wartime self.

This book also examines the question of what the veteran-memoirist consciously and subconsciously remembered of his wartime experiences, and which memories found their way into his personal narrative. In doing so, it draws upon a number of studies rooted in the neurosciences. In their comprehensive study of war and remembrance in the twentieth century, Jay Winter and Emmanuel Sivan pulled together major lines of scientific understandings of memory, finding that most experiences leave long-term memory traces, although these may differ in density. The weight of a memory determines how well it may be recollected, and density is moulded by the degree of drama or uniqueness of an experience. Perhaps unsurprisingly, these scholars found that memories of combat were particularly dense, and therefore long-lasting, because the experience was intensely personal and dramatic. Harrowing moments conferred further density upon a memory. ${ }^{21}$ In his study of over 1,000 Second World War British veterans, psychologist Nigel Hunt also found that many of the strongest memories held by these men pertained to battle. The sheer horror of their experiences on the battlefield remained active and tenacious in their recollections. ${ }^{22}$ Among the field of neurosciences, links between emotion and memory are now well-established. Ulrike Rimmele et al. find that 'emotion enhances the subjective sense of remembering', granting an increased subjective intensity of memory and higher confidence in the accuracy of remembering. ${ }^{23}$ Broadly speaking, therefore, the reconstructive nature of individual memory means that experience is transformed into recollection by uniqueness, importance, imaginative elaboration, and confabulation. ${ }^{24}$ Not all of the serviceman's time was spent in close proximity to violence and danger; indeed a common aphorism holds that war is 90 per cent boredom and 10 per cent action. It is that 10 per cent of violent, exciting, terrifying experience which is remembered and recorded in the Second World War veterans' tale - as one memoirist of Bomber Command mused, 'who the hell can

21 Jay Winter and Emmanuel Sivan, 'Setting the Framework', in War and Remembrance in the Twentieth Century, p. 12.

${ }^{22}$ Nigel C. Hunt, Memory, War and Trauma (Cambridge: Cambridge University Press), pp. 140-3.

23 Ulrike Rimmele, Lila Davachi, Radoslav Petrov, Sonya Dougal, Elizabeth A. Phelps, 'Emotion enhances the subjective feeling of remembering, despite lower accuracy for contextual details', Emotion, 11:3 (2011), 553.

${ }^{24}$ Hunt, Memory, War and Trauma, p. 118. 
write a book about boredom?'25 The Veterans'Tale thus takes as its focus that 10 per cent of remembered and recorded experience 'at the sharp end' of war.

Beneath the surface of personal recollection lurks the sharp rock of war-related trauma, upon which a veteran's memory may easily founder. Dominick LaCapra identifies trauma as 'a disruptive experience that disarticulates the self and creates holes in existence.' ${ }^{26}$ Furthermore, as Hunt and Robbins note, trauma - such as may be sustained on the battlefield - disrupts the processing of memory, existing as an unconscious, dissociated recollection which later may be prompted into consciousness through stimulation of reminders. ${ }^{27}$ As such, it is necessary to keep in mind Paul Ricoeur's caution of the necessity of acknowledging that individual memory may prove an inherently unstable source. ${ }^{28}$ Sometimes it is difficult to identify whether a veteran-memoirist's memory has been corrupted or simply erased by traumatic experience. Equally, it is possible to over-identify trauma in these narratives and attribute every silence or inaccuracy to psychological damage. Nevertheless, The Veterans' Tale argues that it is possible to navigate these challenges, frequently with the help of the veteran-memoirist himself. A number of the authors in this study endured psychological breakdown, or some form of what is now termed 'post-traumatic stress disorder', and their accounts proffer important evidence about the impact of wartime trauma and 'battle fatigue' upon the author's own sense of self. Rather than lamenting the ways in which trauma erases memory, therefore, it is more productive to consider how the act of creating a memoir helped traumatised veterans to articulate recoverable memories as an act of catharsis.

As Thomson pointed out in a recent new edition of Anzac Memories, the field of 'memory studies' has become closely enmeshed with an 'autobiographical age' among historiography of war and society. ${ }^{29} \mathrm{As}$ works of life-writing, war memoirs have a distinctive family connection to the literature of auto/biographical studies. Theories connected to the field of auto/biographical study prove enormously helpful in approaching the veterans' tale, particularly in terms of helping to move past a thorny 'truth' versus 'fiction' problem which lingers around these narratives.

25 John Wainwright, Tail-End Charlie (London: Macmillan, 1978), p. 26.

26 Dominick LaCapra, Writing History, Writing Trauma (Baltimore: Johns Hopkins University Press, 2001), p. 41.

${ }_{27}$ Nigel C. Hunt and Ian Robbins, 'Telling Stories of the War: Ageing Veterans Coping with Their Memories through Narrative', Oral History, 26:2 (1998), p. 59.

${ }_{28}$ Paul Ricoeur, Memory, History, Forgetting (Chicago: University of Chicago Press, 2004), p. 80 .

29 Alistair Thomson, Anzac Memories: Living with the Legend, rev. ed., (Monash: Monash University Publishing, 2013), p. 1. 
Fussell suggests that the war memoir is not in fact a personal history but is rather 'a kind of fiction', in which the imposition of literary devices of lexis, syntax, structure, and plot when turning memory into linear prose narrative undermine the 'truth' of lived experience. ${ }^{30}$ Auto/biographical theory suggests differently, positing that attempting to recover an individual's past solely by matching up a person's recollection with established 'fact' severely limits the usefulness of these texts. As Mark Freeman notes, 'if we think of "truth" in this context only in terms of its faithful correspondence to what was, then autobiographical texts must indeed be deemed illusory and fictional.' Crucially, therefore, he argues that there is little reason to think of truth in such a 'limited and simplistic' way. ${ }^{31}$ Similarly, Laura Marcus muses that very few critics of auto/biographical writing would demand that auto/biographical truth should be viewed solely in terms of literal verifiability. She suggests that the seemingly intractable problem of 'referentiality' - the kind and degree of 'truth' that can be expected from autobiographical writing - may be resolved by discussion of the author's intentions and motivations. If the autobiography is 'sincere' in an attempt to understand self and experience, and to make these clear to others, then the 'auto/biographical intention' must be received seriously. ${ }^{32} \mathrm{~A}$ key line of enquiry in The Veterans' Tale is thus to interrogate the intention and function of war memoir, deconstructing the veterans' motives for recovering and communicating experience, and the processes by which they attempted to retain the integrity of their narratives in order to bear witness as 'truthfully', in accordance with their own views, as possible.

Furthermore, within the field of auto/biographical study, it has long been recognised that life-writing is a process of 'collusion' between past and present. ${ }^{33}$ The creation of an autobiographical text stems from, as James Olney has argued, 'the vital impulse to order that has always caused man to create. ${ }^{34}$ The Veterans' Tale thus posits that penning a war memoir allowed the veteran to shape and order his recollections of the past, imposing pattern and coherency upon experience. The narrativisation and emplotment of memory on paper granted a precious second reading of experience, offering the former serviceman a valuable space for reflection

30 Fussell, The Great War and Modern Memory, p. 310.

31 Mark Freeman, Rewriting the Self: History, Memory, Narrative (London: Routledge, 1993), p. 32.

32 Laura Marcus, Auto/Biographical Discourses: Theory, Criticism, Practice (Manchester: Manchester University Press, 1994), p. 3.

33 Roy Pascal, Design and Truth in Autobiography (London: Routledge \& Keegan Paul, 1960), p. 11.

34 James Olney, Metaphors of Self: The Meaning of Autobiography (Princeton: Princeton University Press, 1972), p. 3. 
upon wartime combat. Indeed, Georges Grusdorf argues that, in its provision of a second opportunity to read experience, autobiographical writing may actually produce a 'truer' representation than the first as it adds consciousness to experience. ${ }^{35}$ Freeman also notes that 'the central feature of rewriting the self [is] the process of conferring new meanings on the past in the light of the present.' In this sense, engaging in an act of autobiography enables a man to reassemble himself in his own likeness at a certain moment of his history. ${ }^{36}$ His image is fixed for eternity, which grants him the opportunity to cogitate at length upon the changes sustained to that self. Whether this process of inner reflection is implicit or explicit in a war memoir, self-knowledge is invariably bound up in autobiographical writing and so the historian gains a valuable glimpse into the veteran's self-fashioning of past and present identities. Dialogue between a memoirist's past and present constructions of self thus reveals something important about the veteran's fashioning of that self at the time of writing. The Veterans'Tale therefore concurs with Jay Winter's suggestion that the stories related by soldiers tell us of their experiences, whilst the act of narration informs us of who they are at the time of telling. ${ }^{37}$ War, as Elaine Scarry notes, forces the combatant to set aside his normative peacetime identity, divesting himself of 'a learned and deeply embodied set of physical impulses regarding his relation to any other person's body.' According to Scarry, through his consent to kill for the nation, the soldier's identity becomes fragmented: war 'unmakes' his sense of self. ${ }^{38}$ Once the soldier stepped back from the battlefield into peacetime civilian life, memoir functioned as a mirror in which to reassemble these pieces. The Veterans' Tale engages with these ideas to demonstrate that, for veterans of the Second World War, autobiographical writing offered a valuable opportunity to reassemble shattered notions of masculine self into a coherent and meaningful image. The interiority and linearity of these narratives is thus an important focus of this study.

Representations of war constitute a pillar of this research. Focusing on core themes of landscape, weaponry, the enemy, and comradeship, this book examines the imagery used by Second World War veteranmemoirists to depict their experiences of battle. It maintains a firm focus on change and continuity within the veterans' tale. As such, it also engages with a body of scholarship which focuses more widely on

${ }^{35}$ Georges Grusdorf, 'Conditions and Limits of Autobiography', in Autobiography: Essays Theoretical and Critical, (ed.) James Olney (Princeton: Princeton University Press, 1980), p. 38.

${ }^{36}$ Ibid., p. 43.

37 Winter, Remembering War, p. 116.

${ }^{38}$ Elaine Scarry, The Body in Pain (Oxford: Oxford University Press, 1985), p. 122. 
cultural representations and images of the Second World War. As Mark Connelly observes, the Second World War is 'a visual war above all else. ${ }^{39}$ Connelly's analysis of the 'peculiar and particular history and memory' that the British nation continues to hold of this war highlights the vast range of books, newspapers, films, documentaries, and artwork which perennially inform Britain's 'popular, national culture. ${ }^{40}$ It was within this context that the veterans' tale of the Second World War was produced over the course of nearly seventy years, and the memoirists' immersion in this collection of visual images and symbols invariably shaped their own descriptions of 'what it was like' to serve in wartime. In his excellent cultural history of the wartime RAF, Martin Francis demonstrates that 'key myths about the flyer were already in place long before 1945.' His outline of how RAF aircrew in particular negotiated cultural images and stereotypes that many found 'simultaneously compelling and repellent' opens the door to similar interrogation of the mediation of self-image and cultural tropes in the memoirs of soldiers and sailors. ${ }^{41}$ The Veterans' Tale thus provides an audit of how veteran-memoirists subscribed to, and challenged, a wider cultural iconography of battle during the Second World War in their depictions of wartime experience.

The veterans' narratives are inspected here through a prism of war as a series of separate but interrelated psychological relationships with landscape, weaponry, the enemy, and comrades. The Veterans'Tale particularly focuses upon the war memoirists' portrayal of their emotional responses to these four dimensions of frontline experience. As such, this book also contributes to the blossoming field of studies in the history of emotions. As emotionally- saturated documents, war memoirs have much to offer this branch of historical enquiry. For British servicemen prior to 1939 , a basic 'language of instincts' was used to describe emotions in war. By the 1960s, a new 'fashionably self-conscious, psychoanalytical style' of war memoirs encouraged a more introspective and confessional narrative of battlefield stories and sensations. ${ }^{42}$ There is thus much to be gleaned from these documents about how the veteran-memoirist self-identified and interpreted his emotional and physiological responses to combat. In a recent endeavour to open up further research in the area of the history of emotions, Jan Plamper's introduction to this field

39 Mark Connelly, We Can Take It! Britain and the Memory of the Second World War (Harlow: Pearson Education, 2004), p. 6.

${ }^{40}$ Ibid., p. 14.

${ }^{41}$ Martin Francis, The Flyer: British Culture and the Royal Air Force, 1939-1945 (Oxford: Oxford University Press, 2008), p. 7.

${ }^{42}$ Joanna Bourke, 'Fear and Anxiety: Writing about Emotion in Modern History', History Workshop fournal, 55 (2003), 120. 
suggested that the history of emotion might be aligned with the study of oral history. ${ }^{43}$ When oral history first gained momentum as a discipline during the 1980s, it gave birth to numerous important theories about how to approach memory as an historical source, a number of which have informed the fashioning of The Veterans' Tale. ${ }^{44}$ Moving oral history under the umbrella of the history of emotion similarly raises questions pertaining to the relationship between emotion and memory. ${ }^{45}$ Whilst Plamper rightfully cautions a need to be mindful of the temporal difference between the experience and memory of emotion, this is the same potentially tricky issue that the historian seeking to distinguish between a veteran-memoirist's lived and remembered experience of war must navigate. In both instances, the answer arguably remains the same. War memoirs are by nature retrospective and have much to say about what a veteran thought he felt, and what he wanted to put on record at the time of writing and publishing his account. If we can accept this as a baseline from which to unravel these documents, we also stand a good chance of further illuminating the emotional significance that the veteran-memoirist attached to his wartime experiences.

The veterans' tale contains a wealth of emotional recollection encoded in emotive language. As historian Barbara Rosenwein observes, such language proffers considerable 'grist for the historian's mill. ${ }^{46} \mathrm{~A}$ key objective of this book is therefore to analyse the imagery and language that veteran-memoirists used to recover and record their experiences in battle. It is also imperative to critically explore the language and imagery which military memoirists select to frame experiences of combat in their narratives as these choices reveal not only the ways in which the veteran comprehended his experiences but also the ways in which he wanted his audience to understand them. On those occasions where language is viewed as inadequate to convey feelings of anguish or shame, silence itself might also be viewed as symbolic. As Jay Winter reminds, silence is frequently a deliberate construction; an active choice may be made to remain silent for a multitude of reasons. ${ }^{47}$ Since superficially unemotional content in these documents is just as revealing as the overtly emotional,

43 Jan Plamper, The History of Emotions: An Introduction, trans. Keith Tribe (Oxford: Oxford University Press, 2015), p. 289.

${ }^{44}$ Ibid., p. 289.

45 Ibid.

46 Barbara H. Rosenwein, 'Problems and Methods in the History of Emotions', Passions in Context: International fournal for the History and Theory of Emotions, www.passionsincontext.de/?id=557.

${ }^{47}$ Jay Winter, 'Thinking about Silence', in Efrat Ben-Ze'ev, Ruth Gino and Jay Winter (eds.), Shadows of War: A Social History of Silence in the Twentieth Century (Cambridge: Cambridge University Press, 2010), pp. 4-11. 
it is salutary to follow Rosenwein's advice to 'read the silences' in veteran memoirs. ${ }^{48}$ The war memoirist's choices and balance of language and silence in his depiction of battle are thus scrutinised in this book as signifiers of the physical, psychological, and emotional impact of combat upon the veteran. Rosenwein's concept of 'emotional communities' - shared systems of feeling in networks of human beings - also exerts a formative influence upon this investigation of veteran memoirs. Published post-war memoirs operated as textual links between an emotional community of military veterans, and it is also possible to identify separate emotional communities within the wider community of post-war veteran memoirists. Published memoirs communicated affective bonds between author and other veterans based on shared experiences of battle during the Second World War. These narratives also functioned as vehicles of communication with a number of other audiences including family, friends, and a wider audience of unknown public readers. Not least, they sought to extend reassurance and guidance to future generations of combatants. Furthermore, Rosenwein's suggestion that emotional communities may avoid expression of some emotions altogether, or only discuss certain emotions within a specific and limited context, also holds import for unpacking veteran memoirs. ${ }^{49}$ The unusual punctuation in the title of The Veterans' Tale signifies its core argument that these narratives ought to be read on a collective, as well as an individual, level. Borrowing and moving on from Hynes' evocative title of The Soldiers' Tale, the placing of the apostrophe opens up discussion of a 'notional tale', or 'one huge story', of the combatant and war. ${ }^{50}$ It also establishes the war memoirist's claims to possession of his individual tale, and to his right as spokesman for the masses of former combatants who were never given the chance to tell their stories; a theme which is strongly emergent in this particular category of military life-writing.

Emotive and sensory depictions of battle have been closely woven into the identity of the modern military memoir ever since its birth in the mid-eighteenth century. Although soldiers' stories are as old as war itself, and the British twentieth-century military memoir has its roots in a long tradition of military life-writing which extends back to the Greco-Roman world, the soldier's tale in its modern form began to emerge from the middle of the eighteenth century. ${ }^{51}$ At this time an unprecedented outpouring of military life-writing witnessed a number of key changes in

${ }^{48}$ Rosenwein, 'Problems and Methods in the History of Emotions'

49 Ibid.

${ }^{50}$ Hynes, Soldiers'Tale, p. xiii.

${ }^{51}$ Yuval Noah Harari, 'Military Memoirs: A Historical Overview of the Genre from the Middle Ages to the Late Modern Era', War in History, 14:3 (2007), p. 295. 
the nature of soldiers' memoirs. Whereas Renaissance military memoirs comprised mostly of facts rather than experiences, and were generally not written by the lower ranks, during the French and Napoleonic Wars of 1793-1815, soldiers' accounts began to privilege descriptions of experience over lengthy lists of facts about the battles in which they participated. ${ }^{52}$ Ramsey labels these subaltern narratives 'affective eye-witness accounts', proposing that at this time the personal story of the soldier began to circulate as a mode of socio-cultural reflection upon war, inviting the public to share in the soldier's sufferings. ${ }^{53}$ Through these cultural changes, the ordinary soldier-memoirist was granted a public voice in addition to an apparatus through which he could challenge both other representations of war and the authority of his social and military superiors. As The Veterans'Tale unfolds, the Second World War memoirists were not slow to take advantage of this well-established forum.

At the other end of the chronological scale, the development of modern technologies during the late twentieth and early twenty-first centuries has shaped the creation of soldiers' tales anew. The rise of the internet enabled autobiographical stories to be shared in online forums or posted on popular websites such as the BBC's 'WW2 People's War' webpage, an online archive allowing members of the public to post and read memories of people's experiences during the Second World War. ${ }^{54}$ The use of helmet-cams attached to soldiers fighting in the recent conflicts in Afghanistan and Iraq has offered a somatic method of telling the combatant's battlefield story. Ascertaining what actually 'counts' as a war memoir in order to distinguish a genre with discrete rules has thus become a notoriously troublesome task, and in an essay indicatively titled 'No Genre's Land' Alex Vernon highlights persistent ambiguities in the war memoir's identity. ${ }^{55}$ Much effort has been expended, particularly in the realm of auto/biographical studies, in trying to define exactly where memoirs fit into the spectrum of life-writing. ${ }^{56}$ Arguably, devoting excessive attention to the complex wrangles over precisely where the latter should be located on the continuum of ego-documents does not much help to further understandings of the narratives themselves.

${ }_{52}$ Harari, Renaissance Military Memoirs, p. 67.

${ }_{53}$ Ramsey, The Military Memoir and Romantic Literary Culture, p. 10.

${ }^{54}$ Lucy Noakes, "War on the Web": The BBC's "People's War" Website and Memories of Fear in Wartime in 21st Century Britain', in British Cultural Memory and the Second World War, (eds.), Lucy Noakes and Juliette Pattinson (London: Bloomsbury, 2013), pp. 60-76.

55 Alex Vernon, 'No Genre's Land: The Problem of Genre in War Memoirs and Military Autobiographies', in Arms and the Self, pp. 1-40.

${ }^{56}$ Marcus, Auto/Biographical Discourses; Linda Anderson, Autobiography (London: Routledge, 2001); Pascal, Design and Truth in Autobiography. 
As Harari acerbically but accurately remarks, 'From the perspective of military history, much of this debate is superfluous. ${ }^{57}$ Instead, he proffers a useful framework of identification, proposing that military memoirs may be diagnosed where they meet the following criteria:

1. They are synthetic narrative texts

2. They are written retrospectively

3. They are written to a considerable extent on the basis of personal memory

4. They deal with a considerable time-span

5. They have their authors appear as protagonists, and

6. They devote considerable attention to martial affairs in which their authors participated as combatants. ${ }^{58}$

To this might be added Hynes' driving criterion that a book constitutes a war memoir when it speaks with 'a voice that is stubbornly distinct, telling us what it was like, for this man, in this war. ${ }^{59}$ Abiding by these principles, The Veterans'Tale does not, therefore, include as veteran memoirs texts which stem from the extensive and nebulous hinterland of military life-writing. This includes co-authored narratives, personal testimony camouflaged as fiction, anthologies of testimony snipped from oral or published accounts, or chapters on the war that are contained within larger autobiographical works. Also excluded from this study are the wide and varied range of accounts that are often labelled as 'memoirs', constituting anything from a couple of hastily- typed pages to abrupt self-published accounts. By focusing on the cadre of Second World War memoirs that were brought out with more commercial publishing houses, it is possible to make use of the records which detail the communication between memoirist and publisher to probe in detail the intention and function of published veteran memoir. In particular, the recently catalogued archive of Leo Cooper, a renowned specialist publisher of military history, offers a veritable treasure trove for investigating the gestation process of published military memoir. Indeed, Cooper's efforts to grant former soldiers a voice, and to allow them 'to erect their own memorial' quietly underpin much of The Veterans' Tale, as many of the memoirs investigated in this book were either published by Cooper or under the Pen and Sword imprint which took over his backlist and catalogues during the $1990 \mathrm{~s} .{ }^{60} \mathrm{~A}$ number of veteran-memoirists who were

${ }^{57}$ Harari, 'Military Memoirs', p. 290.

58 Ibid., p. 290.

${ }^{59}$ Hynes, Soldiers'Tale, p. xv.

${ }^{60}$ Leo Cooper, All My Friends Will Buy It: A Bottlefield Tour (Staplehurst: Spellmount, 2005), p. 192. 
ultimately published elsewhere also had some professional dealings with Leo Cooper. The Leo Cooper Archive thus proffers a unique insight into how what John Keegan calls the 'two worlds' of publishers and soldiers have come together. ${ }^{61}$

Within the wider discussion of the history and identity of military lifewriting, the published Second World War military memoir has a distinctive history in its own right. Within this the identities of wartime and post-war published narratives have acquired their own unique personae. Official restrictions upon the wartime publication of military memoirs lent these books a very different flavour to their post-war brethren. On 7 April 1942, a Cabinet decision was taken to impose a comprehensive ban on the publication of service reminiscences. In some cases this ban was relaxed, but these memoirs were required to pass through intense official scrutiny to ensure that they did not compromise military personnel, equipment, locations, tactics, and (perhaps most importantly from an official perspective) did not offer scathing opinions of the conduct of the war. Heavily censored to ensure that they did not endanger public morale, wartime-published military memoirs frequently contained hearty, if rather clumsy, messages of encouragement to the struggling British nation. By November 1945, the ban was lifted, although procedures were put in place by each Service to ensure that personnel were made aware of the provisions of the Official Secrets Acts. Soldiers and naval personnel were advised to contact either the War Office or the Admiralty should they wish to publish on matters arising from or pertaining to their wartime service. The Air Ministry simply drew the attention of airmen leaving the Service to the Official Secrets Acts. ${ }^{62}$ During the late 1940s and 1950s, some official safeguards against the publication of information which might reveal wartime secrets remained in place, but these operated on a much reduced scale. By the mid-1950s, publishers were only required to submit the manuscript of a war memoir for official vetting if the author was still a serving officer or had been involved with intelligence work during the war. It remained vital to seek official approval in the latter circumstance, as the memoirist might reveal methods or identities of colleagues which could prejudice future intelligence operations in the event of another war. Other circumstances which necessitated official permission to publish involved reference to any wartime secrets that the government wished to be kept secret, such as the existence of ULTRA. During the 1950s, publishers or authors who were

${ }^{61}$ John Keegan, foreword, All My Friends Will Buy It, p. ix. This archive is currently held by the University of Reading.

${ }^{62}$ The National Archives (hereafter TNA) /CAB 21/2683, Sir Henry Markham to E. Bridges, 15 November 1945. 
anxious or unsure about the regulations could apply to Admiral George P. Thomson, Secretary of the Admiralty, War Office, Air Ministry and Press Committee, for advice. ${ }^{63}$

Once the war ended and official restrictions began to lift, momentum for publishing military memoirs gathered pace rapidly. Since the 1950s a snowball effect occurred in the publication of memoirs of military veterans of the Second World War, with more appearing in each decade until around 2010, when numbers began to sharply fall off as that generation of veterans faded away. The years between 1945 and 1950 witnessed a turbulent transition from a wartime to a peacetime publishing climate, from which it is difficult to draw satisfactory conclusions about military life-writing in the immediate post-war period. Until 1950, many publishing houses were cautious about commissioning too many war-related titles. With the end of paper rationing in 1949, however, publishers' precious supplies of paper were no longer restricted to a relatively narrow pool of titles deemed valuable to the nation's morale. Correspondingly, publication lists gradually began to include an expanding variety of personal accounts which recounted experiences of war on many different fronts, and from the perspective of a multifarious array of combatants. This expansion was helped along by the new demand for cheap, mass market paperbacks that had emerged from the late 1930s. However, many of the combat narratives which appeared in the late 1940s were frequently constructed in the same manner as the censored, and often overtly propagandised, wartime-published texts, perhaps because they too were often written during the war itself and left largely in their wartime-edited forms. This especially tended to be the case with posthumous publications, such as Guy Gibson's Enemy Coast Ahead (1946) and Keith Douglas's Alamein to Zem Zem (1946), but some living authors such as Nicholas Monsarrat in his Three Corvettes (issued in October 1945) also did not revise the material they had drafted during the war, although in some instances they did add new forewords. ${ }^{64}$ Many combat narratives of the mid-to-late 1940s thus had a somewhat confused, hybrid identity, and are difficult to integrate into discussions of the character of military memoir as it began to emerge with greater distance from the war during the 1950s. The transition to the unique subjectivities

${ }^{63}$ Re-named the Services, Press and Broadcasting Committee in the 1960s, and re-titled the Defence, Press and Broadcasting Advisory Committee in 1993. Despite the changes of name, the committee remained constant in its provision of guidance to press and publishers on subjects in which considerations of national security might be involved.

${ }^{64}$ Guy Gibson, Enemy Coast Ahead (London: Michael Joseph, 1946); Keith Douglas, Alamein to Zem Zem (London: Editions Poetry, 1946); Nicholas Monsarrat, Three Corvettes, 10th ed. (London: Mayflower, 1972 ). 
which categorise the subgenre of veteran memoir first occurred around 1950. Correspondingly, this date, rather than 1945, constitutes the first bookend of The Veterans'Tale.

Within the history of the Second World War military memoir, it is virtually impossible to identify accurate statistics pertaining to the titles of war memoirs published. This is due to fluctuating classifications of 'memoirs' across the period, and inconsistencies within the British National Bibliography's (BNB) cataloguing system which date back to 1950. Nevertheless, a number of broad patterns and trends in the appearance of the veterans' tale are certainly traceable and proffer a valuable scaffolding for this research. The $\mathrm{BNB}$ catalogues indicate that during the 1950s, the tales of commandos, submariners, and prisoners-of-war were in especial demand. Unlike the POW memoirs published from the 1970 s onwards, the narratives of the 1950 s and early 1960 s carried similar qualities of derring-do to the accounts penned by former members of elite special forces such as the Special Air Service and the Commandos. The POW narratives of this era are especially interesting, as they mostly fall into the category of 'escape and evasion' stories, rather than the tales of atrocity which later emerged from the narratives of surviving Far East Prisoners of War (FEPOWs). Since 1955, the appearance of war memoirs published by former army personnel including officers and other ranks has been relatively consistent. The naval war, however, was at its most prominent in military life-writing during the 1950s, with accounts written by both surface sailors and submariners appearing in the publishing lists. After 1960, the British submariner memoir rather faded away, and only a few accounts by surface sailors appeared after that. Royal Navy veteran-memoirs also remained predominantly written by officers. The fighter pilots' Battle of Britain narratives, too, were mostly authored by officer pilots. Only one of the large number of fighter aircrew memoirs published between 1956 and 2006 upon which this research draws was composed by a former sergeant pilot. ${ }^{65}$ In contrast, the Bomber Command personal narratives were almost equally penned by sergeant and officer pilots alike. However until Miles Tripp's The Eighth Passenger appeared in 1969, the post-war testimonies of bomber aircrew remained virtually non-existent. Subsequently, throughout the late 1980s and early 1990s, Bomber Command veterans released a surge of personal narratives in order to 'set the record straight' about the controversial wartime strategic air campaign before it was too late. ${ }^{66}$

65 Bill Rolls, Spitfire Attack (London: William Kimber, 1987).

${ }^{66}$ Frances Houghton, "The "Missing Chapter": Bomber Command Aircrew Memoirs in the 1990s and 2000s', in British Cultural Memory and the Second World War, pp. 153-70. 
The publishing climate for military memoirs changed significantly between 1950 and 2010. The 1950s and early 1960s were dominated by the narratives of senior commanders - particularly the former Desert Generals - who frequently used their memoirs to battle amongst themselves to justify strategic decisions, claim glory, and shift culpability. Although several memoirs of ordinary junior officers in the Army were also published during this period, the voice from the ranks was largely muffled until the end of the 1960s. Alex Bowlby's graphic and irreverent memoir of service in the Italian Campaign, The Recollections of Rifleman Bowlby, represented one of the very first published narratives to document the 'worm's eye' view of the Second World War. Having been rejected on seventeen occasions by publishing firms, it was not accepted for publication until 1969. Whilst this rejection was mostly (and not wholly unreasonably) wrapped up in publishers' fears of a libel suit, a broader social reason for the lack of memoirs published from ordinary soldiers was also apparent. When Recollections began to sell well under Leo Cooper's new imprint, that publisher offered Sphere the opportunity to bring the book out as a mass paperback edition. However, Sir Anthony Cheetham, the editor of Sphere, expressed regret that he could not accept the book for publication, explaining that he perceived little market for an ordinary, non-ranking soldier's tale. 'The reason', he asserted, 'is a simple sociological one. It has neither the weight and authority of a General's memoirs. ${ }^{67}$

Once the 'Great Men' of the wartime British military had had their say, however, the 1970s proved something of a watershed in the production of war memoirs from the rank and file of the Army. The RAF, too, began to claim a greater share of attention as memoirs of former aircrew trickled out in steadily increasing numbers. A myriad of reasons may be attributed to the exponential swell in numbers of war memoirs entering publication since then. Since the war itself, the Second World War has formed an integral part of a well-embedded national 'pleasure-culture of war' in Britain. ${ }^{68}$ Interest was intense among post-war generations of youngsters who remained fascinated by the conflict in which their fathers had fought, and lapped up tales of that war with enduring eagerness. This ready-made market for war stories meant that the memoirs of Second World War veterans increasingly offered an enormously attractive commercial prospect to publishers, who began to bring out more and more titles. Thanks also to seminal histories of battle such as John Keegan's

${ }^{67}$ University of Reading, Leo Cooper Archive (hereafter UoR LC/) A/2/79, Sir Antony Cheetham to Leo Cooper, 24 October 1969.

${ }^{68}$ Dawson, Soldier Heroes, p. 4. 
The Face of Battle (1976) and Martin Middlebrook's series of books on Bomber Command, beginning with The Nuremburg Raid (1973), an 'experiential turn' in the history of warfare ensured that 'ordinary' servicemen's experiences of war also became a flourishing topic of interest within the scholarly domain. Other factors also influenced the emergence of veteran memoirs thirty years after the Second World War. From the late 1970 s onwards, the veterans also began to reach middle-age and to think about retirement. For many, this life-stage offered the leisure and inclination to reflect upon their wartime experiences, and to think about making a record for their families and for posterity. After the Falklands War of 1982 re-ignited cultural memories of 'Britain's Finest Hour', the British nation also began to commemorate the Second World War with ever-increasing levels of pomp and circumstance, triggering a seemingly endless round of anniversaries and remembrance events. With renewed focus upon the commemoration of the Battle of Britain, RAF memoirs became particularly prevalent in the 1980 s, but the numbers of accounts by armoured personnel and infantry also rose significantly. By the time of the great cycle of fiftieth anniversaries of the war in the 1990s, Leo Cooper was inundated with pleas to consider manuscripts. The impact of the commemorative cycles upon the production of these narratives from the 1990s onwards is indicated by the sheer number of veterans who sent their manuscript to Leo Cooper explaining that they thought the public interest in the war would generate sufficient sales to render publication commercially attractive to the publisher. ${ }^{69}$ The hopes of making a little money from the publication of a war memoir undoubtedly prompted some veterans' decisions to try their luck and submit their manuscripts to publishing houses, but as The Veterans'Tale examines, the memoirists offered multiple other public and private explanations of their reasons for publishing a war memoir as well. The veterans' own stated reasons for writing and releasing a war memoir therefore particularly concern and inform this study.

The language and content of published veteran memoirs also underwent significant changes over the post-war decades. Throughout the 1950s and most of the 1960s, the war memoirs of junior officers and other ranks were written in the ubiquitous 'stiff upper lip' vein. The style was clipped and the veteran did not linger over descriptions of death and injury to the same graphic extent for which his later counterparts opted. Furthermore, until legislation governing what was acceptable and what was 'obscene' in publications was amended in 1959 and 1964, very little of a sexual or lurid nature found its way into

${ }^{69}$ See the Leo Cooper Archive held by the University of Reading. 
veteran memoirs. 'Colourful' soldiers' language became more explicit in memoirs at the beginning of the 1970s, and by the end of the 2000s discussions of homosexuality had begun to appear far more openly in the veterans' tale. Veteran-memoirists also became more candid about emotional subjects, such as the experience of war neurosis and survivor's guilt. Nevertheless, there were also important continuities in the subgenre of post-war published veteran memoirs. Among the different services, experiences of battle tended to be represented in very similar ways between 1950 and 2010. Remarkably similar imagery, metaphors, and ideas consistently shaped the veterans' representations of their interactions with the landscape, weaponry, enemy, and comrades that comprised their battle experience.

The great range of military memoirs published by British veterans between 1950 and 2010 offers an overwhelming quantity of fruitful evidence about the diversity of frontline experiences. In order to enable some conclusions to be drawn about the nature of post-war published veteran memoir, a number of parameters necessarily restrain the scope of The Veterans'Tale. To streamline the source base, focus is firmly fixed on 'combatant' accounts of frontline service. An unapologetically purist definition of 'combatant' is employed here, centring upon accounts written by servicemen whose primary martial function was to confront the enemy directly in battle. The Veterans'Tale thus addresses those memoirs of former infantrymen, tank crew, aircrew, and sailors whose principal military task in wartime was to kill or be killed. Furthermore, for the sake of recovering and clarifying the 'ordinary' combatant's recollections of frontline experience, this study does not include narratives penned by 'extraordinary' personnel. Regrettably, special forces soldiers who fought with the Special Air Service, Special Boat Service, Long Range Desert Group, Commandos, or other irregular units such as 'Popski's Private Army', must await their own investigation. Nor does it focus upon the captivity memoirs of ex-POWs, or those who served in an intelligence capacity, as theirs are different types of collective tales yet again. Memoirs documenting the so-called 'forgotten' war in the Far East have also been excluded as the deeply racialized perceptions of the Japanese enemy that shape these texts render the veterans' representations of combat very different to those of their comrades who faced a German or Italian opponent. Nevertheless, in certain parts of the book, a small number of narratives from across these omitted categories are drawn upon to make illustrative comment upon the construction, intention, and function of veteran memoir.

There is, of course, a highly gendered dimension to reading these veteran memoirs which requires mention. John Tosh, Michael Roper, and 
Martin Francis have rightfully articulated a need for historians of seemingly closed-off all-male institutions such as the British armed forces to bear in mind that it is problematic to remove women completely from the scene as if they had no impact whatsoever on male identity and experience. ${ }^{70}$ RAF aircrew who participated in the Battle of Britain or Bomber Command's campaigns were stationed on domestic shores, with varying levels of access to military and civilian women. As Francis explains, the 'romantic distractions of the flyer ensured that the wartime RAF was never a closed homosocial world in which masculinity operated independently of a female presence. ${ }^{71}$ Relationships with women prominently studded the memoirs of aircrew veterans, but they were universally woven into all the other veteran narratives too. Women particularly maintained an emotional presence in these accounts of frontline experiences, with veterans recording that letters from wives and sweethearts had a significant impact upon their mood and feelings of ability to cope with war. The location of women in veteran memoirs is thus also unquestionably deserving of its own study. However, since The Veterans' Tale is ultimately concerned with the memoirists' representations of confronting the enemy in the field, and given that women were precluded from frontline combatant roles during the Second World War, this part of the tale must unfortunately also await another day.

This book thus maintains a firm focus on the memoirs of veterans who experienced 'the sharp end' of war as fighting men of junior or other rank, serving with the Royal Air Force's Fighter and Bomber Commands, armoured and infantry units within the British army, and the submarines and 'small ships' (destroyers, corvettes, and armed trawlers) of the Royal Navy. Among each of these branches of the armed services, veteran accounts most commonly clustered around specific wartime battles, campaigns, or theatres of war. For example, Fighter Command memoirs typically chronicled the Battle of Britain which took place in the summer and autumn of 1940, whereas Bomber Command narratives predominantly related the night-time strategic bombing campaign conducted by the crews of the 'heavy' four-engined Lancaster aircraft between 1942 and 1945. The Royal Navy's veteran-memoirists tended to relate tales of convoy escort duty and submarine wars in the northern waters of the North Sea, Atlantic, and Arctic Circle. Army narratives of former infantrymen and armoured crew typically recounted experiences of battle in key campaigns across North Africa between 1940 and 1943, Italy

${ }^{70}$ Michael Roper and John Tosh (eds.), Manful Assertions: Masculinities in Britain since 1800 (London: Routledge, 1991), p. 3.

71 Francis, The Flyer, p. 85. 
between 1944 and 1945, and North-West Europe between 1944 and 1945. It is on these areas of common ground that The Veterans'Tale concentrates, exploring in detail similarities and differences in the veteranmemoirists' experience, understanding, and representation of these defining wartime events.

Important distinctions must also be drawn between wartime-published memoirs and their post-war counterparts. Although the former are naturally valuable in their own right, these books differed considerably to those published in peacetime because they lacked the temporal gap which shaped the unique reflective dimension of veteran memoir interrogated in this book. Nevertheless, it would be inappropriate to comment upon the post-war narratives without recognising the influence of their wartime antecedents. As Elizabeth Bruss observes, autobiography responds to what precedes and surrounds it at the time of writing. ${ }^{72}$ Since post-war and wartime published memoirs form a distinct genre of military life-writing, some awareness of the latter is essential to a study of the former. For this reason, Richard Hillary's The Last Enemy (1942), Nicholas Monsarrat's Three Corvettes (1945), Keith Douglas'Alamein to Zem Zem (1946), and Guy Gibson's Enemy Coast Ahead (1946) are frequently drawn upon to explain or illustrate discussion of the postwar memoirs. Several of the post-war memoirists were clearly wellacquainted with these earlier well-known narratives. For example, Stuart Hills's By Tank into Normandy (2002) announced that the author had thoroughly enjoyed reading Douglas' book as it contained 'some marvellous pen portraits' of mutual acquaintances and fellow officers. ${ }^{73}$ Former fighter pilot, Geoffrey Page, met Richard Hillary whilst they were both hospitalised and recovering from severe burns at East Grinstead during the war. In an amicable exchange of insults, Page confirmed that he had enjoyed reading The Last Enemy, although he described its author in less positive terms as a 'supercilious bastard' ${ }^{74}$ Such open acknowledgement of familiarity with the work of the wartime memoirists is rare in the postwar memoirs, but the presence of the earlier narratives lingers in the veterans' tale nonetheless.

Finally, the veteran-memoirists of the Second World War came from a mix of social backgrounds, but some trends in their publication of memoirs can be discerned. Veterans who recorded their experiences of

72 Elizabeth Bruss, Autobiographical Acts: The Changing Situation of a Literary Genre (Baltimore: Johns Hopkins University Press, 1976), p. 166.

73 Stuart Hills, By Tank into Normandy (London: Cassell, 2002), p. 54.

${ }^{74}$ Geoffrey Page, Shot Down in Flames: A World War II Fighter Pilot's Remarkable Tale of Survival (London: Grub Street, 1999), p. 116. Previously published as Tale of a Guinea Pig (London: Pelham Books, 1981). 
holding commission in the Royal Navy were mostly drawn from the middle classes. Although the Second World War helped to rework some of the traditional class and rank hierarchies in the RN, naval officers between 1939 and 1945 were most likely to possess a middle-class background. ${ }^{75}$ There was more social diversity among the army veterans, who ranged from Nicholas Mosley who was the son of British fascist leader Oswald Mosley and came from an aristocratic background and held junior rank in the 2nd Battalion, London Irish Rifles; through Alex Bowlby, who came from a middle-class background and had been privately educated at Radley, but who refused to take a commission and carried out his wartime service in the ranks of the 2 nd Battalion of the Rifle Brigade; to John Kenneally, who was the illegitimate son of a prostitute and served time in a military prison before winning the Victoria Cross in Africa. Among the RAF, the dominant cultural representation of the Battle of Britain pilots as mainly consisting of well-off young boys wrenched out of university has been substantially challenged by research into the backgrounds of 'the Few' ${ }^{76}$ Admittedly, however, the memoirs of these aircrew do little to dispute the conventional popular impression of the socially privileged identity of the fighter pilot. The vast majority of the veteran-memoirists of 'the Few' were indeed drawn from a middle-class milieu and exposed to a specific range of cultural images which conditioned their expectations of war as a public-school-inspired adventure of sport, chivalry, and glory. Nevertheless, there are some difficulties in using social class as a tool with which to approach the post-war published veteran memoir. Should one deal with the class status of the memoirist at the outset of his wartime experiences, or the class into which he fell at the time of writing many years later? Disentangling these questions is not particularly straightforward. It is also problematic to attempt to discern if and how the memoirist's own subjective perception of his pre-war, wartime, and post-war class identities altered. British society changed so much before, during, and after the Second World War that using social class as a tool to illuminate aspects of the veterans' tale is of limited assistance. As such, questions of class have been addressed here mainly where the veteran himself seemed to feel it was relevant to his expectations, experiences, and recollections of combat.

In terms of the architecture of this book, Chapters 1-2 of The Veterans' Tale survey the provenance of the Second World War veteran memoirs.

${ }^{75}$ Penny Summerfield, 'Divisions at Sea: Class, Gender, Race, and Nation in Maritime Films of the Second World War, 1939-60', Twentieth Century British History, 22:3 (2011), 330-53.

${ }^{76}$ Tony Mansell, 'Flying start: educational and social factors in the recruitment of pilots of the Royal Air Force in the interwar years', History of Education, 26:1 (1997), 71-90. 
Considering published war memoir as a unified genre, these chapters delve deep into the archives of major publishing houses to examine the veterans' stated reasons for producing and publicly distributing their war experiences in book form, and the physical processes of writing and publishing a military memoir in post-war Britain. Chapters 3-6 address the veterans' tale itself, analysing the narrative content of these military memoirs. Respectively focusing on themes of landscape, weaponry, the enemy, and comradeship, these four chapters probe the memoirists' literary representations of experience in the front line. Chapters 7-8 explore how ex-servicemen put their historical records to work both in private and public, assessing themes of self-fashioning and claiming agency over wartime experience in the veterans' tale. 